\title{
The Relationship between Organizational Change and Employee's Organizational Commitment in State-owned Enterprises
}

\author{
Pan Junzhu \\ School of business, Sichuan University, Chengdu ,610065, China
}

Keywords: Organizational change; organizational support; Organizational commitment

\begin{abstract}
In China, state-owned enterprises are special but extremely important type of enterprises. In recent years, with the constant changes of political, social and economic environment, state-owned enterprises are facing a series of organizational changes. The study on organizational commitment is of practical significance to employ, motivate and attract employees.
\end{abstract}

\section{Introduction}

On August 18, 2014, Xi Jinping chaired the fourth meeting of the Central Committee's Comprehensive Deepening Reform Group, which discussed the reform of state-owned enterprises. In China's market economy, state-owned enterprises is an important part of the organization, and state-owned capital accounts for about $19.3 \%$ of the national economy. The state-owned enterprises in China not only participated in market competition, but also have background of state participation, which is not conducive to the healthy development of market economy to a certain extent.

In the face of political, economic and social environment changes, market competition continues to deepen, enterprises began to carry out organizational change. In the process, the organizational commitment of state-owned enterprises employees on the results of organizational change larger, but the personality, values and motivation of different personality traits of employees have a great influence on the reaction and cognition of employees. The key factors are intermediate variables before organizational change and organizational commitment.

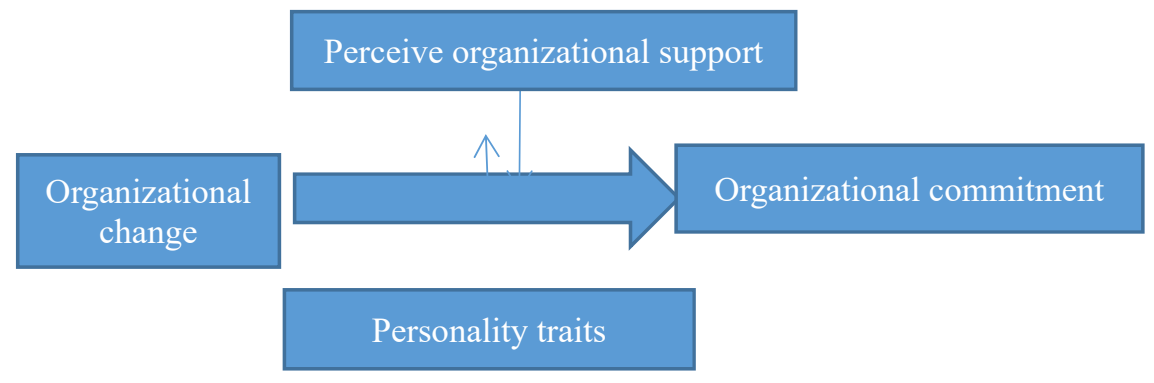

\section{Theoretical basis}

Organizational Change: It is the process of organizational development. The study have changed the number of departments and the relationship between subordinates. The organizational process is undergoing changes, the workload and rhythm of members of the organization are undergoing sudden and temporary drastic changes. Many scholars agree that employees' organizational commitment to change. It is necessary to discuss the relationship between organizational change and organizational commitment, as well as the important factors affecting organizational commitment.

Personality traits: Personality develops from three aspects: ID, ego and superego. Traits include two aspects: character and characteristics, which have a great influence on individual behavior. Each individual behaves differently in terms of personality traits, thus forming a unique personality. This paper chooses the "Big Five" dimensions of Big Five Personality Theory as the research variables that affect employee organizational commitment under Organizational change. At the 
same time, employees with different personality traits have different cognition of organizational support.

Organizational support: This paper mainly explores employees' perceived organizational support from four dimensions, which are emotional support, instrumental support, superior support and peer support. Organizational developmental support for individuals is classified into two categories: emotional support and instrumental support for personal development. In this paper, perceived organizational support is regarded as a research affecting employee organizational commitment , which provides practical guidance for enterprise management decision-making.

Organizational commitment: Scholars expressed organizational commitment as a kind of behavior of employees' loyalty, identification. Researchers generally agree that high levels of organizational commitment are beneficial to organizational development, and that employees with high levels of organizational commitment are more likely to engage in behaviors other than their own work roles. Among them, emotional commitment mainly refers to employees' emotional dependence on the organization, their recognition of the organization's cultural values, and their sense of pride and honor as a member of the organization.

\section{Research hypothesis}

The relationship between organizational change and organizational commitment

When organizational change environment began to change, employees have a lot of uncertainty. Fear stems from psychological state of most human beings, employees have different understandings of the threats and challenges brought by the change. The greater the degree of change, the greater the uncertainty, and the more the organizational commitment of employees will be affected. Then put forward the following hypothesis:

H1 organizational change has a negative impact on organizational commitment.

H1a organizational change has a negative impact on emotional commitment.

H1b organizational change has a negative impact on sustained commitment.

H1c organizational change has negative influence on normative commitment.

The relationship between organizational change and organizational commitment based on different personality traits

In the study of the relationship between organizational change and organizational commitment, there are few specific studies on the role of personality traits. And personality traits play a key role in the cognition and response of individuals to the outside world. Different cognition determines the degree of organizational commitment. Based on the characteristics of different dimensions of personality traits, the following hypothesis is made:

The relationship between $\mathrm{H} 2 \mathrm{a}$ neurotic employee organizational change and organizational commitment is negative.

$\mathrm{H} 2 \mathrm{~b}$ extraverted employees have a negative relationship between organizational change and organizational commitment.

The relationship between organizational change and organizational commitment is positive.

There is no correlation between organizational change and organizational commitment of $\mathrm{H} 2 \mathrm{e}$.

The relationship between personality traits and organizational support

As personality traits affect individual cognition, organizational support is a kind of cognition in this study, which depends on individual perception. Different personality traits have different degrees of perception of organizational support, so the following hypothesis is made:

H4a neuroticism was positively correlated with organizational support.

$\mathrm{H} 4 \mathrm{~b}$ extraversion was positively correlated with perceived organizational support.

$\mathrm{H} 4 \mathrm{c}$ openness to experience is positively correlated with organizational support.

The humaneness of $\mathrm{H} 4 \mathrm{~d}$ is positively related to the sense of organizational support.

The sense of responsibility of $\mathrm{H} 4 \mathrm{e}$ has no correlation with the sense of organization support. 


\section{Sample information}

The subjects of this research are employees of large state-owned enterprises. A total of 358 questionnaires were issued in this study, and 358 were actually recovered, all of which were valid questionnaires, with the recovery efficiency reaching $100 \%$. The distribution of gender ratio, age, education and management categories was shown in the table below:

Table 1 Gender

\begin{tabular}{|c|c|c|c|c|}
\hline \multirow{3}{*}{ Active } & male & 200 & 55.9 & 55.9 \\
\cline { 2 - 5 } & female & 158 & 44.1 & 44.1 \\
\cline { 2 - 5 } & total & 358 & 100 & 100 \\
\hline
\end{tabular}

Table2 Age

\begin{tabular}{|c|c|c|c|c|}
\hline \multicolumn{2}{|c|}{} & Frequency & Percentage & Effective percentage \\
\hline \multirow{4}{*}{ Active } & Under the age of 22 & 37 & 10.3 & 10.3 \\
\cline { 2 - 5 } & $23-28$ & 94 & 26.3 & 26.3 \\
\cline { 2 - 5 } & $29-34$ & 113 & 31.6 & 31.6 \\
\cline { 2 - 5 } & $35-40$ & 54 & 15.1 & 15.1 \\
\cline { 2 - 5 } & Above 41 years & 60 & 16.8 & 16.8 \\
\cline { 2 - 5 } & total & 358 & 100 & 100 \\
\hline
\end{tabular}

Table3 Education

\begin{tabular}{|c|c|c|c|c|}
\hline \multicolumn{1}{|c|}{} & Frequency & Percentage & Effective percentage \\
\hline \multirow{4}{*}{ Active } & High school and below & 63 & 17.6 & 17.6 \\
\cline { 2 - 5 } & college & 154 & 43 & 43 \\
\cline { 2 - 5 } & Undergraduate & 121 & 33.8 & 33.8 \\
\cline { 2 - 5 } & graduate & 19 & 5.3 & 5.3 \\
\cline { 2 - 5 } & Dr. & 1 & 3 & 3 \\
\cline { 2 - 5 } & total & 358 & 100 & 100 \\
\hline
\end{tabular}

\section{Empirical analysis results}

Reliability analysis: In this study, the 5-point scale was used in all the test scales, with 5 points indicating very consistent, and 1 point indicating very inconsistent.

Organizational change: There are 7 problems in the organizational change test scale, and its mean value is taken as the characteristics of organizational change. The coefficient of this variable is 0.798 , indicating that the problem consistency is relatively ideal and acceptable.

Table4 Reliability statistics of organizational change scale

\begin{tabular}{|c|c|c|}
\hline Cronbach's Alpha & Cronbachs Alpha & Item \\
\hline 798 & 799 & 7 \\
\hline
\end{tabular}

Big five personality traits: There are 15 questions in the big five personality trait scale, which is composed of 3 questions in each dimension in the original test scale. Many scholars believe that the original scale has a good reliability and validity, and the rating coefficient of this scale is 0.706 , and the consistency is within the acceptable range.

Table 5 Reliability statistics of the five personality traits scale

\begin{tabular}{|c|c|}
\hline Cronbach's Alpha & item \\
\hline 706 & 15 \\
\hline
\end{tabular}

Sense of organizational support: There are a total of 13 questions in the scale of perceived organizational support. The scale developed by ling wenquan and others was selected as four 
dimensions including emotional support, tool support, superior support and peer support. The rating coefficient of this scale is 0.960 , which has a very good consistency.

Table 6 reliability statistics of organizational support scale

\begin{tabular}{|c|c|}
\hline Cronbach's Alpha & item \\
\hline 960 & 13 \\
\hline
\end{tabular}

\section{Research results}

The relationship between organizational change and organizational commitment

The table below shows that the degree of organizational change is negatively correlated with organizational commitment, significantly negatively correlated with emotional commitment, positively correlated with continuous commitment, and negatively correlated with normative commitment. The results are verified as follows:

$\mathrm{H} 1$ organizational change has a negative impact on organizational commitment.

H1a organizational change has a negative impact on emotional commitment.

$\mathrm{H} 1 \mathrm{~b}$ organizational change has a negative impact on the continuous commitment.

H1c organizational change has negative influence on normative commitment establishment.

Table 7 Correlation between organizational change and organizational commitment

\begin{tabular}{|l|l|c|c|c|c|c|}
\hline \multicolumn{2}{|c|}{} & $\begin{array}{r}\text { Degree of } \\
\text { organizational } \\
\text { change }\end{array}$ & $\begin{array}{r}\text { Emotional } \\
\text { commitment }\end{array}$ & $\begin{array}{r}\text { Continued } \\
\text { commitment }\end{array}$ & $\begin{array}{c}\text { Normative } \\
\text { commitment }\end{array}$ & $\begin{array}{c}\text { Organizational } \\
\text { commitment }\end{array}$ \\
\hline \multirow{2}{*}{$\begin{array}{l}\text { Degree } \\
\text { organizational } \\
\text { change }\end{array}$} & $\mathrm{N}$ & - & $-233^{* *}$ & $121^{*}$ & $-153^{* *}$ & $-107^{*}$ \\
\cline { 2 - 7 } & $\mathrm{N}$ & 358 & 0 & 0.022 & 0.004 & 0.044 \\
\hline
\end{tabular}

The relationship between organizational change and organizational commitment of different personality traits

When individual personality trait belongs to neuroticism, there is no significant correlation between organizational change and organizational commitment. It is assumed that the relationship between organizational change and organizational commitment of $\mathrm{H} 2 \mathrm{a}$ neurotic employees is negative. Organizational change is significantly correlated with organizational commitment when individuals show extroversion. It is assumed that the relationship between organizational change and organizational commitment of $\mathrm{H} 2 \mathrm{~b}$ extroverted employees is negative. When individuals show openness to experience, there is no obvious correlation between organizational change and organizational commitment, and it is assumed that there is no correlation between organizational change and organizational commitment of employees with openness to H2c experience. When the individual is appropriate, organizational change and organizational commitment show a more significant negative correlation. It is assumed that the positive relationship between organizational change and organizational commitment of employees is not established, and the relationship between organizational change and organizational commitment is more significant negative correlation. When individuals show responsibility awareness, organizational change has a significant negative correlation with organizational commitment, and it is assumed that there is no correlation between organizational change and organizational commitment of employees with $\mathrm{H} 2 \mathrm{e}$ responsibility awareness.

The role of organizational support between organizational change and organizational commitment

Descriptive analysis results: Sample from the whole, perceived organizational support up to 4, organizational commitment is 3.3 , reflected in a typical characteristic of the state-owned enterprises, the state-owned enterprise welfare treatment is good, employees enjoy the relatively rich resources, organizational support work better, however, employees' organizational commitment only show the 
general level, and high level does not match, organizational support is an expression of the state-owned enterprises staff generally lack of energy..

Table 8 Descriptive statistics of organizational support and organizational commitment

\begin{tabular}{|c|c|c|c|}
\hline & The average & The standard deviation & N \\
\hline $\begin{array}{c}\text { Sense of organizational } \\
\text { support }\end{array}$ & 3.9854 & 93769 & 358 \\
\hline Organizational commitment & 3.3116 & 82661 & 358 \\
\hline Emotional support & 3.8667 & 95818 & 358 \\
\hline Tool support & 3.8904 & 1.03172 & 358 \\
\hline The superior support & 4.0503 & 1.11909 & 358 \\
\hline
\end{tabular}

\section{Correlation analysis}

Liu xiaoping (2002) found that there was a significant relationship between organizational support and organizational commitment, while four dimensions of organizational support had different effects on organizational commitment. At the same time, superior support and colleague support have more influence on organizational commitment of employees than emotional and instrumental support. The following table shows the relationship between organizational support and organizational commitment in this study. The test results are as follows:

$\mathrm{H} 3$ perceived organizational support has a positive impact on organizational commitment.

H3a emotional support had a positive effect on organizational commitment.

The $\mathrm{H} 3 \mathrm{~b}$ tool support has a positive impact on organizational commitment.

H3c superior support has a positive effect on organizational commitment.

H3d colleagues supported the establishment of positive effects on organizational commitment.

Table 9 Correlation between organizational support and organizational commitment

\begin{tabular}{|c|c|c|c|c|c|c|c|}
\hline & & $\begin{array}{c}\text { Sense of } \\
\text { organizational } \\
\text { support }\end{array}$ & $\begin{array}{l}\text { Organizational } \\
\text { commitment }\end{array}$ & $\begin{array}{l}\text { Emotional } \\
\text { support }\end{array}$ & Tool support & $\begin{array}{c}\text { The } \\
\text { superior } \\
\text { support }\end{array}$ & Peer support \\
\hline \multirow{3}{*}{$\begin{array}{l}\text { Organizational } \\
\text { commitment }\end{array}$} & Pearson & $.650^{* *}$ & 1 & $.624^{* *}$ & $.658^{* *}$ & $.559^{* *}$ & $.514^{* *}$ \\
\hline & significant & .000 & _- & .000 & .000 & .000 & .000 \\
\hline & $\mathrm{N}$ & 358 & 358 & 358 & 358 & 358 & 358 \\
\hline
\end{tabular}

The relationship between personality traits and organizational support

The lower the score of neuroticism, the lower the sense of organization support. Therefore, the more neurotic and openness to experience individuals are, the lower their sense of organization support. Neuroticism to experience is correlated with the sense of organization support. There was no significant correlation between extraversion and perceived organizational support. The lower the score of agreeableness, the higher the sense of organizational support. Therefore, the more the individual is inclined to the sense of appropriateness and responsibility, the higher the sense of organizational support. The results were verified as follows:

There was no positive correlation between H4a neuroticism and perceived organizational support, and there was a significant negative correlation.

There was no positive correlation between $\mathrm{H} 4 \mathrm{~b}$ extraversion and perceived organizational support, and no significant correlation.

$\mathrm{H} 4 \mathrm{c}$ openness to experience has a positive correlation with the sense of organizational support, which is not true, and shows a significant negative correlation.

The humaneness of $\mathrm{H} 4 \mathrm{~d}$ is positively related to the sense of organization support.

$\mathrm{H} 4 \mathrm{e}$ sense of responsibility has no correlation to the sense of organization support and is not established, showing a significant positive correlation. 


\section{Summary of research result}

H1 organizational change has a negative impact on organizational commitment. The model of this study is due to the historical reasons of state-owned background enterprises. Therefore, the organization should carry out employee communication activities or change policies before the change begins, so as to improve employees' understanding and trust of the change. It is better to develop supporting incentive measures to enable employees to build a sense of ownership.

H1a organizational change has a negative impact on emotional commitment. 0zag (2002) proved that employees' trust were significantly correlated in corporate reform. In this study, when a large amount of work is added to the organization temporarily and the organizational structure changes, employees' trust in the organization will be negatively affected. Employees complain about the "constant changes" of the enterprise have no trust in the reform.

$\mathrm{H} 1 \mathrm{~b}$ organizational change has a negative impact on the continuous commitment. Under the background of state-owned enterprise, the interests of the employees to get position of special care, to maintain organizational change and form a complete set of effective is helpful. H1c organizational change has negative influence on normative commitment establishment. It shows the importance of management measures such as formulating the change plan and publicizing the change in advance.

The negative relationship between organizational change and organizational commitment of $\mathrm{H} 2 \mathrm{~b}$ extraverted employees is established. When employees' individual performance for extroversion, the higher the organizational change, organizational commitment is lower, the reason is enthusiasm and initiative. When the organization change, the environment is tight, people have time for conversation and activities and atmosphere. Encourage them to launch employee activities to help improve employees' enthusiasm and facilitate the smooth progress of the reform.

The positive relationship between organizational change and organizational commitment of $\mathrm{H} 2 \mathrm{~d}$ employees is not established. When employees' individual performance for agreeableness, employees tend to be on behalf of others. The relationship between the organizational change of $\mathrm{H} 2 \mathrm{e}$ and its organizational commitment is irrelevant. Individual employee performance itself for the target plan and implement with perseverance and strong motivation, is too easily affected by external change, it is belong to self control and drive strong people. So the organization to change to its impact is not big with the goal of conditions.

\section{Acknowledgement}

This study added the big five personality trait variables and organizational support variables to obtain the uniqueness of enterprise employees under the state-owned background and establish a model of guiding significance to the actual management work. In the future, we can focus on the development of organizational commitment scale, organizational support scale, and even the increasingly mature big five personality trait scale, and study the characteristics of organizational change and employee commitment changes in different enterprise development stages without cultural background. At the same time, the effects of demographic variables, such as length of service, age, rank and family status, on employees' organizational commitment or sense of support, as well as the impact of organizational commitment on employees' performance, were taken into account to turn the theoretical research results into actual employees' productivity.

\section{References}

[1] Hannan M T, Freeman J. Structural Inertia and Organizational Change[J]. American Sociological Review, 1984, 49(2):149-164.

[2] Ling W Q, Zhang Z C. The research on the structure model of Chinese employee's organizational commitment[J]. Journal of Manegementences in China, 2000(3-4):362.

[3] Ling, Wen Quan, and Z. C. Zhang. "The research on the structure model of Chinese employee's organizational commitment." Journal of Manegementences in China 3-4(2000):362. 
[4] Allen N J, Meyer J P. The measurement and antecedents of affective, continuance and normative commitment to the organization[J]. Journal of Occupational Psychology, 2011, 63(1):1-18.

[5] Moscon D B, Souza J J D. Is it possible to integrate affective and instrumental ties into the same concept?: managers' perspective on commitment to the organization[J]. Organ Soc, 2012, 19(61):357-373.

[6] Allen N J, Meyer J P. Affective, Continuance, and Normative Commitment to the Organization: An Examination of Construct Validity[J]. J Vocat Behav, 1996, 49(3):252-276. 